\title{
Electronic Information and Education Environment as a Training Tool for Resource-Efficient Management of Polymer Waste Processing
}

\author{
Tamara B. Chistyakova \\ Computer Design and Control Department \\ Saint-Petersburg State Institute of Technology \\ St. Petersburg, Russia \\ nov@technolog.edu.ru
}

\author{
Inna V. Novozhilova \\ Computer Design and Control Department \\ Saint-Petersburg State Institute of Technology \\ St. Petersburg, Russia \\ novozhilova@bk.ru
}

\begin{abstract}
Industrial engineering of modern enterprises in order to modernize them, improve the quality of products and introduce new production management systems leads to the need to form highly qualified personnel support, which is especially important for processes of polymer waste processing in order to reduce environmental pollution and return valuable raw materials to production. For resource-saving control of polymer waste processing processes functional structure of electronic information and educational environment is proposed, which allows to form individual paths and to carry out practicaloriented training of specialists involved at each stage of life cycle of production of technical polymer products from secondary raw materials. The electronic information and educational environment proposed in the work was successfully tested on the basis of the training center "Polymer-ecology" of SaintPetersburg State Institute of Technology with cooperation with LLC "Plastic processing plant named after "Komsomolskaya Pravda". The use of the environment as a tool to ensure the quality of training of highly qualified personnel of polymer industry enterprises allows to increase the professional level of specialists in the field of development of composite polymer mixtures based on secondary polymer materials and technologies of their processing into technical products with improved environmental and consumer characteristics.
\end{abstract}

Keywords- engineering team; polymer recycling; polymer waste; secondary raw materials; e-learning

\section{INTRODUCTION}

In "Industrial Development Strategies for Processing, Recycling and Disposal of Production and Consumption Wastes up to 2030", Approved by Order of the Government of the Russian Federation No. 84-r of 25 January 2018, as one of the main areas of action for the task of establishing and expanding a national industrial industry and processing infrastructure, disposal and decontamination of wastes, their use as secondary raw materials for production of new products is indicated the necessity to create a highly qualified personnel reserve, as well as training, retraining and advanced training of

Work is performed with financial support of Fund of infrastructure and educational programs of RUSNANO by request of LLC "Plastic processing plant named after "Komsomolskaya Pravda", contract No. 06/61/19/40 (01УM) 19 of April 04, 2019 industry personnel in waste treatment and disposal [1,2].

Polymer wastes, partially recovered in the process of solid municipal waste treatment, as well as formed in the process of production and use of plastic products, are promising to be used as secondary resources for production of technical products (polymer film, carving products, polymer pipes, packaging materials, containers, fasteners, heat-sound insulating material, etc.). At the same time, the main difficulty lies in separation and isolation of pure fractions from mixed wastes, as local and common heterogeneities of composition of composite mixtures can be present, which accidentally vary, and which are difficult to describe quantifiably [3, 4].

One of the tools of resource saving, waste treatment and recycling is development of personnel support system of polymer industry enterprises [5], which provides on the basis of development and introduction of innovative technologies complex life cycle management of technical polymer products from secondary raw materials with improved ecological and consumer properties.

Thus, the development of an electronic information and educational environment for comprehensive training of specialists in the field of resource-saving management of polymer waste processing is a pressing, socially significant and economically viable task.

\section{Formation OF TRAINING PATH FOR SPECIALISTS IN THE FIELD OF POLYMER WASTE PROCESSING}

The difficulty of controlling the process of polymer technical products production is due to the presence of a changing (unpredictable) composition of raw materials, multifactor interactions and connections arising in the course of the process, diversity of physical and chemical processes of secondary raw materials and materials processing, variety of technological equipment, a large number of controlled parameters, sensitivity to the occurrence of scrap in the selection of control effects, as well as strict requirements to environmental indicators of production [3, 6]. Therefore, in order to train specialists in the field of resource-saving control of polymer materials processing processes, it is necessary to apply a complex approach, which takes into account all stages 
of the life cycle of the technical product. Taking into account the requirements of professional standards, the personnel target groups include the following specialists involved in each stage of the technical product life cycle: specialists to ensure the production cycle of secondary polymer materials, technical and economic assessment of the life cycle, monitoring and ensuring the safety of the production environment, as well as automated production management using digital technologies [5, 7]. The training path methodology is based on a frame description and includes the steps shown in Fig. 1:

1) Define a target personnel group $(T P G)$ for training $F r^{(1)}$ $::=\left\langle T P G, Q^{(1)}, A^{(1)}\right\rangle$, where $F r^{(1)}$ - frame prototype " $T P G$ ", components of which are attributes $Q^{(1)}$ and its characteristics $A^{(1)}$. Target personnel groups are given in Fig. 2.

2) Creating a set of professional competences $(P C s)$ for training $T P G F r^{(2)}::=\left\langle P C s, Q^{(2)}, A^{(2)}>\right.$ based on an analysis of Generic Labour Functions $(G L F)$ of the respective professional standards for each TPG. The list of PCs is given in Fig. 2.

3) Development of practical-oriented training modules for learning results $(P C s)(T M) F^{(3)}::=\left\langle T M, Q^{(3)}, A^{(3)}\right\rangle$, given in Fig. 2.

4) Development of e-learning course $(E L C) F^{(4)}::=<E L C$, $Q^{(4)}, A^{(4)}>$. Training complexes are used to learn the competency results of training, allowing taking into account the characteristics of the object of study, to accumulate expert knowledge in the field of process control, as well as to form competency-oriented training results.

5) Development of control and measuring material (CMM) $F r^{(5)}::=\left\langle C M M, Q^{(5)}, A^{(5)}\right\rangle$. $C M M$ as test jobs are used to quantify $P C s\left(q_{1}{ }^{(5)}\right)$. For qualitative assessment of educational results $(E R)$ the instructor is given the opportunity to set additional situations at the object of study; monitor the actions of the trainee $\left(q_{2}{ }^{(5)}\right)$ and modes of operation of the subject of study $\left(q_{3}{ }^{(5)}\right)$; analyze and evaluate the trainee 's actions based on the results of training protocols $\left(q_{4}^{(5)}\right)$.

6) Final evaluation of $E R$ development of $P C s \mathrm{Fr}^{(6)}::=$ $<E R, Q^{(6)}, A^{(6)}>$. To evaluate the final $E R$, criteria grid is used, which compares the training criteria and the results achieved, and allow the instructor to formalize the evaluation process based on the results of the practical task. The result of the training of specialists in the field of polymer waste processing is the formation of a certificate of polymer technical product production taking into account the requirements of the product market, environmental safety requirements and economic efficiency of each stage of the life cycle and production as a whole. The certificate of manufacture of the polymer product from the secondary raw material includes description of the raw material preparation process, equipment data, tooling and tools, ranges of technological modes of the injection casting process, requirements to the product quality indicators, environmental safety requirements, as well as technical and ecological production indicators. The product certificate is formed based on the results of combining reports for each stage of the life cycle of the polymer product with unique properties. At the same time results of work of each stage (stage) are transferred to the subsequent, and data of the report of the previous stage are input data for studying and performance of the subsequent practical tasks.

\section{Functional Structure of The Electronic EDUCATIONAL AND INFORMATION ENVIRONMENT}

In order to implement the proposed path of training of specialists in the field of polymer waste processing in the form of electronic training, an electronic information and educational environment has been developed, including electronic information and educational resources in the field of polymer processing and production, a set of information and telecommunication technologies, appropriate technological means and ensuring the full development of educational results [8-10]. The enlarged functional structure of the environment, presented in Fig. 3, includes: information support (database of technological regulations and maps, which contains information on finished products, raw materials and materials, technological modes of production, equipment, database of professional standards, trainees, educational and methodological materials); algorithm support (module for formation of individual training paths of specialists, module for formation of technical polymer product production certificate), user interface (trainees), instructor interface, administrator interface, expert interface.

The core of the electronic information and educational environment is training complexes, which allow on the basis of mathematical models of key processes (drying, extrusion, injection casting) to carry out research of cause-and-effect relations of the object of study, to determine technological modes of equipment for obtaining polymer products with specified quality requirements, as well as to simulate the occurrence of abnormal situations in order to train specialists in the skills of accident-free operation of technological processes.
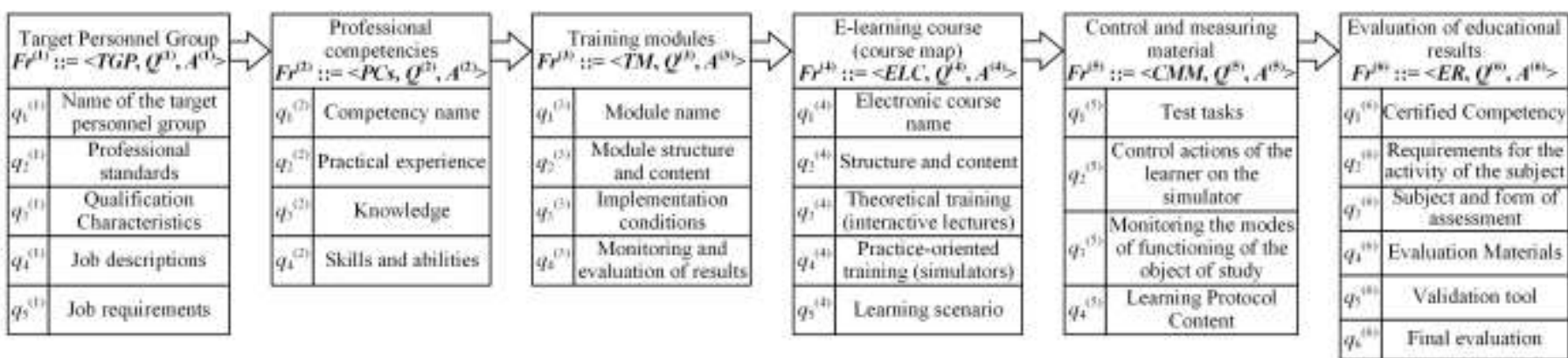

Fig. 1. Process of formation of training path of specialists in the field of polymer waste processing 


\begin{tabular}{|c|c|c|c|c|}
\hline \multirow{2}{*}{$\begin{array}{l}\text { Target persosnel groap in } \\
\text { sccordance with professtonal } \\
\text { standards }\end{array}$} & \multirow{2}{*}{$\begin{array}{l}\text { Generalized job functions } \\
\text { (Professional Competencies) }\end{array}$} & Training Modules & Task Description & \multirow{3}{*}{$\begin{array}{c}\text { Report Cuatent } \\
\text { Report L. The key processes fot } \\
\text { the production of a given } \\
\text { technical product based on } \\
\text { technologies for processing } \\
\text { secondary polymeric materials }\end{array}$} \\
\hline & & & & \\
\hline Marketer & $\begin{array}{l}\text { PCI. Developmenth and } \\
\text { implementation of marketing } \\
\text { programs using masketiog max } \\
\text { tools }\end{array}$ & $\begin{array}{l}\text { innowative products of the } \\
\text { polymer industry using a } \\
\text { marketing mix (is the TMio) }\end{array}$ & $\begin{array}{l}\text { - techical prodost based on } \\
\text { technotoges for processing } \\
\text { secondary polymeric materials }\end{array}$ & \\
\hline \multirow[b]{2}{*}{ Product Safery Specialist } & \multirow{5}{*}{$\begin{array}{l}\text { PC3, Laboratory and analytical } \\
\rightarrow-\text { suppont for the developenent of } \\
\text { composite materals. }\end{array}$} & \multirow{2}{*}{$\begin{array}{c}\text { TMII e Environmental } \\
\text { safety of prodaction and } \\
\text { product from recycled } \\
\text { polymeric materialss }\end{array}$} & \multirow{4}{*}{$\begin{array}{l}\text { 2) Formulation of a composite } \\
\text { mixture based on sesondary } \\
\text { polymeresic maserials for the } \\
\text { manufacture of technicicl products } \\
\text { with specified quality requirements }\end{array}$} & 75 \\
\hline & & & & $\begin{array}{l}\text { Report 2. The formulation and } \\
\text { technological properties of the }\end{array}$ \\
\hline Composite Material & & \multirow{3}{*}{$\begin{array}{c}\text { TM2, a Devolopment and } \\
\text { testing of topical composite } \\
\text { maxteures bastd on } \\
\text { secondary polymeric } \\
\text { materialso }\end{array}$} & & \\
\hline Deretopment Spectalist & & & & +12 \\
\hline & & & \multirow{3}{*}{$\begin{array}{l}\text { 3) The choice of units and } \\
\text { technological modes of equipment far } \\
\text { the production of potyroes prodocts } \\
\text { from recycled materials in } \\
\text { accordance with the repairements of } \\
\text { the tecthologeal regulations }\end{array}$} & $\begin{array}{l}\text { Report 3. Techuical } \\
\text { charactenstics of eguinment and }\end{array}$ \\
\hline $\begin{array}{l}\text { Product Testing } \\
\text { Specialist }\end{array}$ & \multirow{4}{*}{$\begin{array}{l}\text { PC4. Conducting a set of } \\
\rightarrow \begin{array}{c}\text { product tests at the stages of } \\
\text { development, production and } \\
\text { certification }\end{array} \\
\rightarrow \text { PC5. Implementation of } \\
\text { technological processes for the } \\
\text { production of polymer } \\
\text { materials }\end{array}$} & \multirow{3}{*}{$\begin{array}{l}\text { TM13, eDigital tectinologies } \\
\text { in the development and } \\
\text { testing of composite } \\
\text { moxtares based on } \\
\text { secondary polymeric } \\
\text { materialso }\end{array}$} & & $\begin{array}{c}\rightarrow \text { ranges of technological peocess } \\
\text { parameters }\end{array}$ \\
\hline & & & & 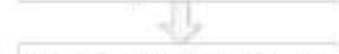 \\
\hline Polymer Productios & & & \multirow{3}{*}{$\begin{array}{l}\text { 4) Searcla for techuological } \\
\text { regulatioss for the production of a } \\
\text { given technical product asing a } \\
\text { database }\end{array}$} & $\begin{array}{l}\text { Report } 4 \text { Technological map of } \\
\text { the production of polymer }\end{array}$ \\
\hline Specialist & & \multirow{3}{*}{$\begin{array}{l}\text { TMA, eAdvanced } \\
\text { technologies and equipment } \\
\text { for processing secondary } \\
\text { polymeric materiatso }\end{array}$} & & products \\
\hline \multirow{2}{*}{$\begin{array}{l}\text { Specialist in autoenated } \\
\text { process control systems }\end{array}$} & \multirow{2}{*}{$\begin{array}{c}\rightarrow \text { PCo. Oryanizatice of work on } \\
\text { the operatios of mitomated } \\
\text { cantrol systems }\end{array}$} & & & +13 \\
\hline & & & \multirow[b]{2}{*}{$\begin{array}{c}\text { 5) Fommation of a quality map of s } \\
\text { polymer product, intermediate } \\
\text { protucts, and waste laking into } \\
\text { accoumt environmestal safery } \\
\text { requirements }\end{array}$} & Report 5. Quality map of \\
\hline $\begin{array}{l}\text { Specialis in providing } \\
\text { comprehensive controf } \\
\text { over the productisu of } \\
\text { comiposite materials }\end{array}$ & \multirow{3}{*}{$\begin{array}{l}\text { PC7. Manitoring coenpliance of } \\
\text { raw materials, semi-finished } \\
\text { products aod fisished producss } \\
\text { of the production of composite } \\
\text { materials witt techinisal } \\
\text { specifications and standards. }\end{array}$} & \multirow{2}{*}{$\begin{array}{c}\text { TM5 } x \text { Automated process } \\
\text { coatrol of resycling } \\
\text { secondary polymer } \\
\text { materials using digital } \\
\text { lechnologys }\end{array}$} & & $\begin{array}{c}\text { products, and production waste } \\
\text { taking into accoint } \\
\text { environmental safety } \\
\text { requirements }\end{array}$ \\
\hline & & & & \\
\hline \multirow{2}{*}{$\begin{array}{l}\text { Specialist in techmical } \\
\text { and ecosomic support of } \\
\text { the full cycle of } \\
\text { development and } \\
\text { implementation of } \\
\text { innovative products }\end{array}$} & & \multirow{2}{*}{$\begin{array}{c}\text { TM6. a Techimical and } \\
\text { ecromamic assessment of the } \\
\text { full cycle of development of } \\
\rightarrow \text { technology for processing } \\
\text { secondary polymer } \\
\text { materialso }\end{array}$} & \multirow{2}{*}{$\begin{array}{l}\text { 6) Feasibility study of an immorative } \\
\text { project for the production of a given } \\
\text { techimical product based on } \\
\text { tecthnologies for processing } \\
\text { secondary polymeric materials }\end{array}$} & \\
\hline & 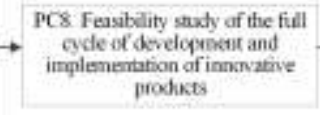 & & & $\begin{array}{l}\text { economic indicators and } \\
\text { detensining the economic } \\
\text { efficiency of the project }\end{array}$ \\
\hline
\end{tabular}

Fig. 2. Structure of personnel support model for resource-saving control of polymer waste processing processes

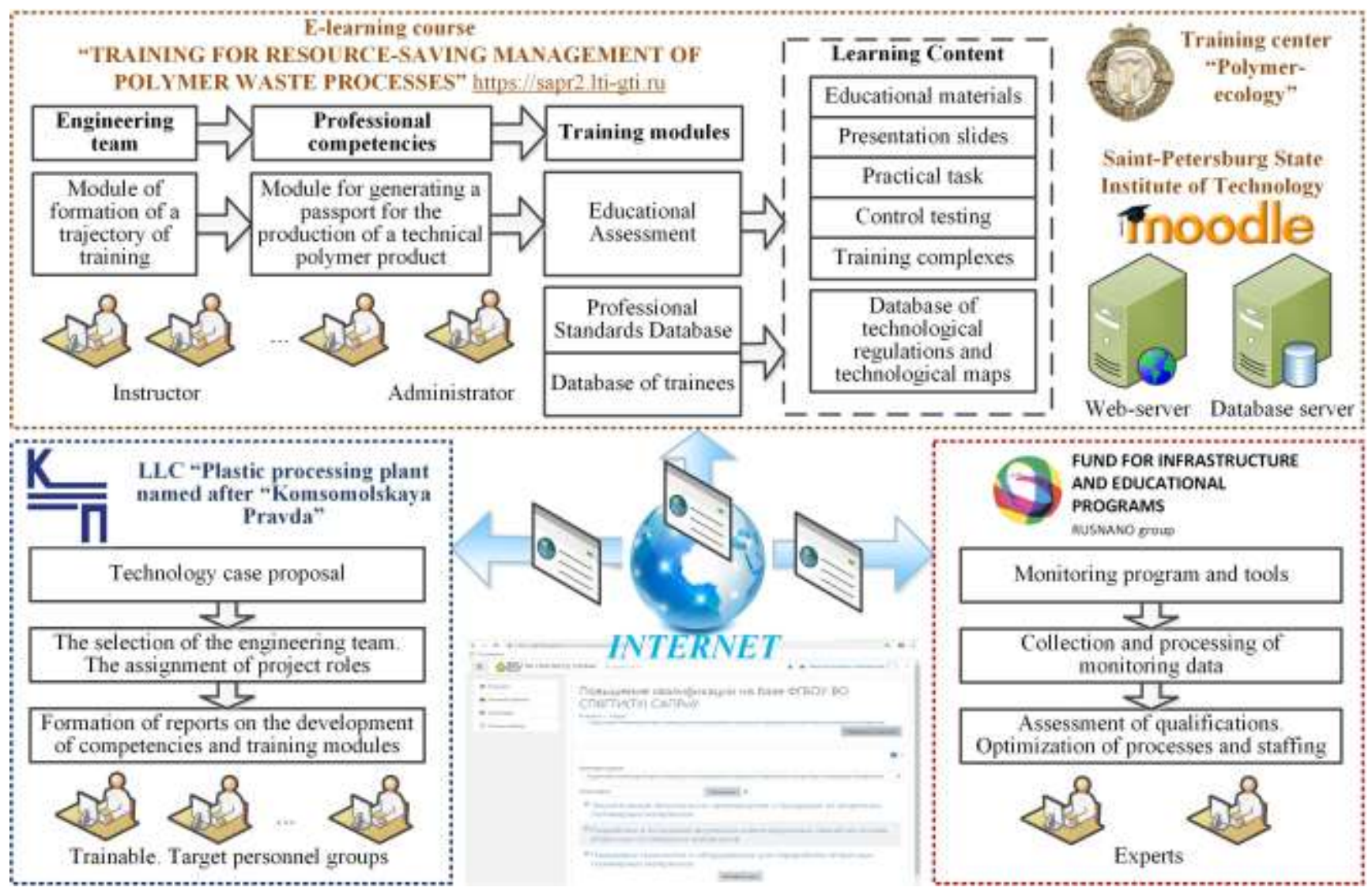

Fig. 3. Structure of the electronic information and education environment 
The information support of the medium is adjusted to different modes of operation of the control object (processes of polymer waste processing) by changing the ranges of the corresponding parameters. This enables the adaptation of the electronic information and education environment to various modifications of the subject of study, which allows using the environment for training in resource-efficient management of various technological processes and production with recycling.

The electronic information and education environment is based on the Moodle learning management system using the SQLite database management system and MS Visual Studio software development environment. The developed environment software has a flexible architecture that supports enhanced functionality by developing and connecting additional software modules.

\section{CONCLUSION}

Testing of the electronic information and educational environment, carried out on the basis of the training center "Polymer-ecology" of Saint-Petersburg State Institute of Technology with cooperation with LLC "Plastic processing plant named after "Komsomolskaya Pravda", confirmed its operability and the possibility of using it to train specialists in solving the problem of reconfiguration of production to a new type of product, problems of determining a formulation of a composite mixture based on secondary polymer materials; as well as tasks of selection of technological modes of polymer product production with specified requirements for quality and consumer properties of final product.

The use of modern technologies of practical-oriented training allows to increase efficiency of production due to introduction of innovative production technologies, to increase quality of produced products, to intensify recycling processes, to improve ecological characteristics, and, above all, to increase professional level of personnel support of industrial enterprises in conditions of digitalization of economy and modernization of system of professional standards and qualifications.

\section{REFERENCES}

[1] Meshalkin V.P. and Khodchenko S.M. The nature and types of engineering of energy- and resource-efficient chemical process systems. Polym. Sci. Ser. D (2017) 10: 347. DOI: 10.1134/S1995421217040128

[2] Makarova A., Tarasova N., Meshalkin V., Kukushkin I., Kudryavtseva E., Kantyukov R., and Reshetova E. (2018). Analysis of the management system in the field of environmental protection of russian chemical companies. International Journal for Quality Research. 12. 4362. DOI: 10.18421/IJQR12.01-03.

[3] Britov V.P., Bogdanov V.V., Nikolaev O.O., and Tubolkin A.E. Activating Mixing in Preparation and Modification of Polymeric Composites. Russian Journal of Applied Chemistry (2004) 77: 119. DOI: 10.1023/B:RJAC.0000024590.08990.84

[4] Barzilovich E.A., Verstakov A.E., Nikulin V.A., Sirotinkin N.V., and Sytov V.A. The influence of the fractional composition of a filler on thermal conductivity of a polymer composition. Polym. Sci. Ser. D (2014) 7: 57. DOI: 10.1134/S199542121401002X

[5] Steblovsky G.A., Britov V.P., and Nikolaev O.O. Novyye podkhody $k$ podgotovke inzhenernykh kadrov $v$ oblasti pererabotki plastmass [New approaches to the training of engineering personnel in the field of plastics processing]. Modern Education: content, technology, quality, 2014, Vol. 1, pp. 53-55.

[6] Panfilov D.A. and Dvorko I.M. The Effect of Oligoethers Based on Secondary Polyethylene Terephthalate and Oligopropylene Diol on the Properties of Novolac Compounds, Polym. Sci. Ser. D (2018) 11: 169. DOI: 10.1134/S1995421218020144

[7] Burmistrov A.N., Kozlova S.P., and Kalinina O.V. Podgotovka inzhenerov $i$ kompleksnykh komand dlya importozameshcheniya $v$ SanktPeterburge [The Training of Engineers and Integrated Teams for Import Substitution in St. Petersburg: Strategy, Experience and Opportunities]. Materials of the scientific forum with international participation: Science Week SPbPU, 2015, pp. 103-110.

[8] Chistyakova T.B., Kozlova S.P., Shlyago Yu.I., and Novozhilova I.V. Scientific and educational complex for resource-saving management of life cycle of processes and processing of secondary polymeric materials, XXI Mendellev Congress on General and Applied Chemistry. Book 3. Abstracts. Saint Petersburg, 2019. p. 197.

[9] Chistyakova T.B. (2019). A Synthesis of Training Systems to Promote the Development of Engineering Competences. Handbook of Research on Engineering Education in a Global Context (pp. 430-442). Hershey, PA: IGI Global. DOI:10.4018/978-1-5225-3395-5.ch036.

[10] Chistyakova T.B. and Novozhilova I.V. "Intelligence computer simulators for elearning of specialists of innovative industrial enterprises," 2016 XIX IEEE International Conference on Soft Computing and Measurements (SCM), St. Petersburg, 2016, pp. 329332. DOI: $10.1109 /$ SCM.2016.7519772 